and scientific benefits and, for that matter, who benefits? Dentistry is already a costly branch of health care to the end user and in the public perception.

As patients we are expected to accept evidence-based treatments. In this event, we cannot accept that dental professionals can advance the patient's interests by conforming to requirements that have a weak evidence base. Please be assured that we are attempting to be constructive in offering these comments.

J. M. Ewart

A. A. Jack

Codsall

DOI: 10.1038/sj.bdj.2010.256

\section{EASTMAN CONCEPTION}

Sir, I recently attended the Eastman Dental Institute with my granddaughter who is receiving excellency in dental treatment there. We were fascinated to see on the directions board in the entrance hall that apart from the Paedodontic Department where we were heading there was also listed the Assisted Conception clinic. As a retired dental practitioner have I missed something?

G. H. Allen

Gerrards Cross

DOI: 10.1038/sj.bdj.2010.257

\section{OFFICIAL FAILURE}

Sir, I was asked by a patient to provide him with a letter in relation to his application for a passport. He had to confirm his right to hold a British passport by verifying the information he had given on his application form by obtaining a letter that showed where he lived in the past three years. This could be provided by a number of individuals or organisations and were listed on the covering letter from the Identity and Passport Service of the Home Office as follows:

- Your bank or building society

- Your employer

- Your landlord or mortgage company

- Your school or university

- Your local authority

- The Department of Work and Pensions

- Your dentist, or only if absolutely necessary, your GP (We ask that you do not trouble your doctor for nonmedical reasons if it can be avoided)

- A Commanding Officer. It would seem from the above that we, as a profession, have failed to establish with officialdom that our time is anything like as valuable as our medical colleagues!

\section{S. I. Morganstein}

London

DOI: 10.1038/sj.bdj.2010.258

\section{EVALUATING TECHNIQUES}

Sir, 'ADAPT' (Aesthetic Dentistry and Professional Testing) invites registered dentists to apply for vacancies as ADAPT evaluators.

ADAPT was formed in 1993 and is accredited as a Specialist Society. The work of the society involves regular meetings where new and improved techniques for the provision of quality aesthetic dentistry are discussed and evaluated. Additionally materials are provided by the dental industry for clinical use and reporting.

Membership entails regular attendance at the monthly evening meetings at a London venue.

Dentists who are interested in taking part are invited to supply a short CV to 'The Chairman ADAPT', email howardstean@ukteeth.com.

Additional background information is available on www.adaptuk.org.

H. Stean By email DOI: 10.1038/sj.bdj.2010.259

\section{MEMBERSHIP TARDINESS}

Sir, I write as a follow-up to your editorial Dental or dentist (BDJ 2009; 207: 656). I recently attended a highly successful BDA section meeting which qualified for verifiable CPD in a core subject. I was asked by some of the invited DCPs why BDA membership is not yet open to them.

DCPs have to be registered with the GDC, they need to have professional indemnity and they need to have CPD. Finally DCPs can and do run dental practices. Why is it then that the BDA is being so tardy in expanding its membership to these essential team members? Does the BDA wish to lose these potentially valuable members to other disparate organisations?

M. Austin

Hove

DOI: 10.1038/sj.bdj.2010.260 